\title{
POTENCIJALI I PERSPEKTIVE RAZVITKA VELEBITSKOG PODGORJA
}

Čedomir Dundović

Pomorski fakultet Sveučilišta u Rijeci

Studentska 2

HR 51000 Rijeka

dundovic@pfri.hr

Damian Dundović

Nacionalna središnjica za usklađivanje

traganja i spašavanja na moru

Senjsko pristanište 3

HR 51000 Rijeka

dundovic@net.hr

Kristina Dundović

Veleučilište u Rijeci

Vukovarska 58

HR 51000 Rijeka

kdundovic@veleri.hr
UDK: 502/504.03(497.5 Velebit)

Izvorni znanstveni članak

Ur.: 2016-11-28

Velebit nije samo najveća hrvatska planina već i jedina primorska planina koja razdvaja dva zemljopisno bitno različita prostora: mediteranski i kontinentalno - planinski odnosno Hrvatsko primorje od Gorske Hrvatske. Primorska padina Velebita obuhvaća Podgorje koje započinje kod Svetog Jurja, gdje se postupno širi i diže do Jablanca, a na južnom dijelu Velebita postupno prelazi u sjeverno - dalmatinsku krašku zaravan. Prirodni uvjeti i smještaj uz more doprinijeli su u prošlosti razvoju šumarstva, ratarske i stočarske proizvodnje, brodarstva, ribarstva, trgovine, lovstva i turizma. Prometna povezanost naselja velebitske primorske padine $\mathrm{s}$ vanjskim svijetom odvijala se oduvijek morskim putem, jer kopnenih prometnica nije bilo, ili su bile u takvom stanju da nisu omogućavale bolje povezivanje naseljenih mjesta. Naseljenost tog područja karakteriziraju mnogobrojni zaseoci koji su međusobno udaljeni $1-6 \mathrm{~km}$ i povučeni od mora u unutrašnjost ponajviše u srednjem vegetacijskom pojasu, jer uz obalu prevladava goli kamen. Na tu razdvojenost naselja utjecala je priroda jer je za naselje trebalo tražiti mjesto koje nije na udaru bure. Zbog toga su se na području velebitske primorske padine, izuzevši grad Senj, razvila 
svega tri važnija obalna naselja: Sveti Juraj, Jablanac i Karlobag. Nedostatak prometne i komunalne infrastrukture te ostalih potrebnih sadržaja (obrazovnih, zdravstvenih, gospodarskih i dr.) razlog su velikom raseljavanju stanovništva ovog kraja koji je u suvremenim uvjetima jedno od najslabije naseljenih područja Republike Hrvatske. Međutim, potencijalne vrijednosti ovog područja ukazuju na mogućnosti njegova bržeg razvitka. Ciljevi i smjernice razvitka upućuju primarno na zaštitu prirodnih i kulturnih dobara uz naglašenu potrebu izrade razvojnih gospodarskih programa. Osim razvitka cestovne mreže koja bi na ovom prostoru potaknula nove razvojne potencijale planiranim mjerama razvitka trebalo bi poticati razvitak gospodarskih djelatnosti (razvitak turizma, marikulture, luka nautičkog turizma, zdravstveno - rekreacijskog turizma, lovnog turizma, voćarstva i vrtlarstva, stočarstva, šumarstva i drvno - prerađivačke djelatnosti, korištenja energetskog potencijala vjetra i sunca, razvoj proizvodnih, trgovačkih i slobodnih carinskih zona i dr.) i društvenih djelatnosti u decentraliziranom sustavu središnjih naselja (obrazovna, zdravstvena i kulturna infrastruktura). U ovom radu poseban naglasak se daje na ocjenu prirodnih potencijala, održivog razvoja i procjenu mogućnosti revitalizacije Podgorja. Radi toga izrađena je SWOT analiza kao osnovna pretpostavka budućeg razvoja.

Ključne riječi: Velebitsko podgorje, potencijali, perspektive razvitka, održivi razvitak, SWOT analiza, gospodarski i društveni razvitak

\section{UVOD}

Velebit kao najznačajnija ortografska prepreka u Hrvatskoj od presudnog je značenja u oblikovanju vremenskih i klimatskih prilika priobalja, dijela Hrvatskog primorja i kontinentalnog zaleđa. Klima na Velebitu pod utjecajem je dviju klimatskih regija: srednjoeuropske i mediteranske. Velebit je granica tih dviju regija jer ih visinom i velikom dužinom razdvaja, iako su prisutni i njihovi prijelazi. Velebit je posebno poznat po svojoj biološkoj raznolikosti. Svojim položajem između mora i kopna na granici dvaju klimatskih područja pruža se $150 \mathrm{~km}$ u duljinu, prosječno $14 \mathrm{~km} \mathrm{u}$ širinu i prosječno $1300 \mathrm{~m} \mathrm{u}$ visinu.

Kada se Velebit gleda s neke veće udaljenosti, doima se kao golemi bedem koji se ispriječio između mora i kopna. Međutim, reljef mu je razveden, a nekoliko prirodnih prijevoja dijeli ga u četiri cjeline: sjeverni, srednji, južni i jugoistočni Velebit. Stoga se i naselja na Velebitu mogu razvrstati u više cjelina: naselja uz more, naselja na podgorskoj zaravni, naselja na uzdužnoj primorskoj terasi, naselja u visokoplaninskoj zoni.

Za primorsku padinu Velebita karakteristične su dvije uzdužne terase koje se poput stuba protežu njegovom duljinom. Prva stuba poznata kao podgorska zaravan počinje kod Svetog Jurja na visini od 60 m, postupno se šireći i uzdižući 
sve do 300 m nad morem kod Jablanca pa se opet suzuje i spušta do Karlobaga i nastavlja sve do sjevernodalmatinske zaravni, do korijena rijeke Zrmanje. ${ }^{1}$

Masiv Velebita je izgrađen od naslaga koje se stratigrafski protežu od razdoblja mlađeg paleozoika do kvartara među kojima dominiraju vapnenci i dolomiti, breče, a u manjoj mjeri i škriljevci.

O posebnostima Velebita dovoljno govore podatci da od ukupno osam nacionalnih parkova koliko ih je u Hrvatskoj, dva su na Velebitu, a od ukupno dva stroga rezervata, jedan je na Velebitu. Ljepotu Velebita, njegov značaj za hrvatsku, europsku i svjetsku floru, njegovu biološku i krajobraznu raznolikost prepoznala je i svjetska organizacija Ujedinjenih naroda (UNESCO) uvrstivši ga u međunarodni program Čovjek i biosfera (M\&B).

U uvjetima globalnog zatopljenja, Velebit s očuvanom prirodom, čistim zrakom, obiljem pitke vode i 363 endemske vrste flore i faune predstavlja raritet u europskim i svjetskim razmjerima. Međutim, sve te ljepote Velebita neće biti vrijedne pažnje ukoliko se u ovom kraju ne potakne novi život, u naseljima stvaranim vjekovima i raseljenima u skoro nekoliko godina.

Čitav taj velebitski prostor moguće je revitalizirati uz određena ulaganja $\mathrm{u}$ prometnu, komunalnu i lučku infrastrukturu te pretvoriti u jedinstveni zdravstveno - rekreacijski i turistički kompleks u kojem bi postojeći stanovnici, ali i budući naraštaji, našli smisao života i opstanka u podvelebitskom kraju.

\section{POVIJESNE ODREDNICE I OCJENA POSTOJEĆEG STANJA}

\subsection{Promet}

U prošlosti je Senj kao središte razvoja velebitskog podgorja bio važno prometno i tranzitno središte. Tu važnost je u posljednjem stoljeću izgubio jer nema željezničku prugu koja bi ga povezivala sa zaleđem.

Prema Senju gravitira područje Like, a kroz grad se slijeva promet prema Dalmaciji i obrnuto. Uzdužnom teritorijalnom cjelinom administrativne jedinice Grada Senja proteže se Velebitski masiv i morski kanal koji određuju osnovne komunikacijske pravce:

- uzdužni jadransko - jonski smjer koji danas opslužuje već zastarjela i nedovoljno protočna Jadranska magistrala

- veze s tri otoka: Krk, Rab i Pag koje se odvijaju preko prirodnih naselja na području Grada Senja.

\footnotetext{
${ }^{1}$ A. LEMIĆ, 2013, 129.
} 


\subsubsection{Kopneni promet}

U povijesti prostor današnje administrativno teritorijalne cjeline obuhvaćao je sljedeće dominantne cestovne veze unutrašnjosti s morem:

- Jozefinska cesta (građena 1775 - 1779) koja završava u Senju

- Vukasovićeva cesta (1784 - 1785) Senj - Sveti Juraj

U suvremenim uvjetima cestovne prometnice na području Grada Senja obuhvaćaju:

A. Državne ceste

- Jadranska autocesta (Rijeka - Senj - Žuta Lokva - spajanje s trasom autoceste Zagreb - Split u čvoru Žuta Lokva)

- D8 - Rijeka - Senj - Zadar (Jadranska magistrala)

- D23 - Duga Resa (D3) - Josipdol - Žuta Lokva - Senj (D8)

- D405 - D8 - Jablanac (trajektna luka)

- D406 - D8 Prizna (trajektna luka)

- D8 - Stinica (trajektna luka)

B. Županijske ceste

- Ž5126 - Sv. Juraj (D8) Krasno - Velika Plana - Gospić (D25)

- Ž5140 - Krasno - Švica - Otočac (D50)

- Ž5182 - Jablanac - B - Štirovača (Ž5126)

Osim ovih cesta postoje i lokalne nerazvrstane ceste, od kojih mnoge nisu asfaltirane.

Stanje cesta može se okarakterizirati kao izrazito slabo, a nedostaju i funkcionalne veze između pojedinih mjesta uz obalu koja su priključena na državnu cestu D8.

Prometnom mrežom Grada Senja omogućeno je povezivanje svih većih naselja uz morsku obalu međusobno povezanih državnom prometnicom D8. Od Senja prema unutrašnjosti vodi državna prometnica D23 koja povezuje primorska naselja u planinskom zaleđu isto kao i županijska prometnica Ž5128 od Sv. Jurja do Krasnog jedinog većeg naselja u zaleđu. ${ }^{2}$

\subsubsection{Pomorski promet}

Pomorski promet i brodarstvo od Senja pa do krajnje podgorske granice ima svoju dugu tradiciju. Prema analizi iz 1849. godine brodarski udio tadašnje monarhije iznosio je $2,49 \%$ u brodovima i $0,66 \%$ u tonama nosivosti. ${ }^{3}$

${ }^{2}$ Prostorni plan uređenja Grada Senja, 2012, 32.

${ }^{3}$ A. LEMIĆ, 2013, 84. 


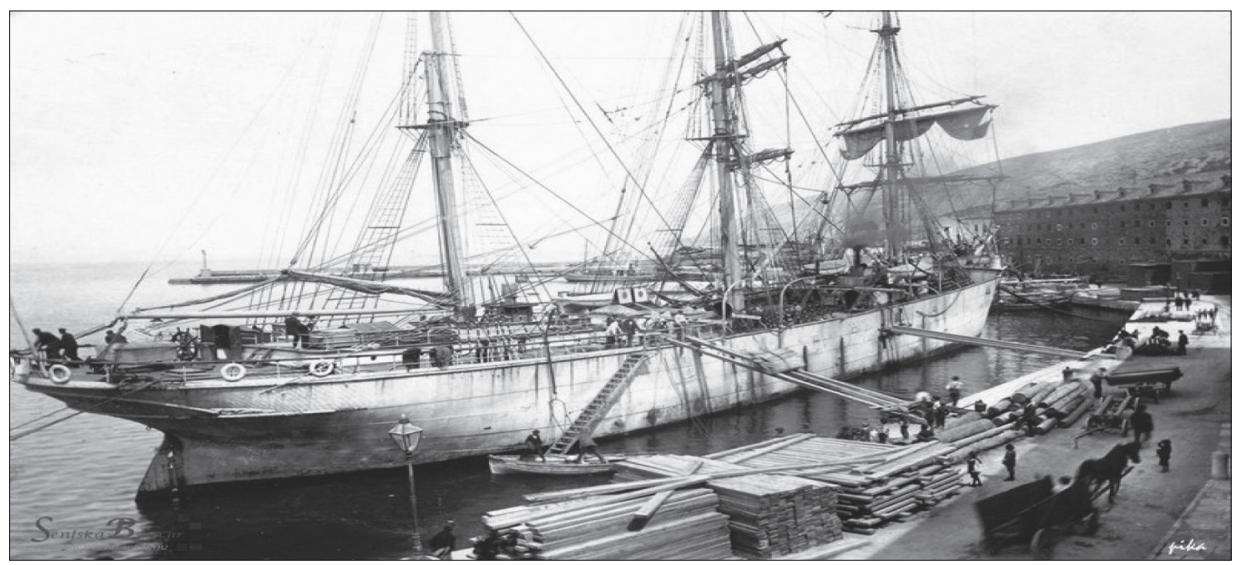

Sl. 1. Senjska luka, izvor: http://www.senjskabura.hr/?ispis=detalji\& novost $=4727 \&$ kat $=79$

Osim Senja brodarstvo je bilo dobro razvijeno i u Sv. Jurju, Lukovu, Kladi, Starigradu, Jablancu, Stinici, Karlobagu i Barić Dragi.

Za prijevoz robe, uglavnom drva, korišteni su jedrenjaci duge i velike plovidbe. Poseban oblik trgovine odvijao se sa stanovnicima otoka s kojima su razmjenjivani proizvodi.

Svaku dobro zaštićenu dragu i uvalu Podgorci su koristili za vezanje svojih brodica. U mnogim primorskim selima i danas stoje isklesane kamene kolone ili bitve.

Nakon Drugog svjetskog rata nije se smjelo imati privatne brodove, pa su ih mnogi morali prodati.

Pomorski promet uglavnom se odvijao brodovima koji su prometovali na relaciji Rijeka - Obrovac, Rijeka - Pag i Rijeka - Rab, pri čemu su veća mjesta imala izgrađena pristaništa, dok bi se iz manjih sela ljudi prevozili barkom do broda.

Izgradnjom prometne infrastrukture posebno željezničke pruge i cestovnih prometnica i povezivanjem luke Rijeka s Europom, luka Senj i luke Podgorja izgubile su određeno prometno značenje.

U postojećim uvjetima pomorski promet određen je:

- lukama županijskog značaja: Senj, Jablanac i Prizna

- lukama lokalnog značaja: Sv. Juraj, Donja Klada, Starigrad, Lukovo, Stinica (Mala Stinica)

- plovnim putovima Senj - Baška, Jablanac - otok Rab, Prizna - Žigljen (Stara Novalja) 
Preko ovog područja odvijaju se tri važna pomorska puta, spoja s najvećim jadranskim otocima Krkom (trenutno u prekidu), Rabom i Pagom. S obzirom na to da je luka Senj u prošlosti imala vezu s otokom Krkom potrebno je preispitati opravdanost i prostorne mogućnosti luke Senj za obnovom trajektne veze Senj - Baška. Na taj način tri trajektne luke (Senj, Jablanac/Stinica i Prizna) dobile bi svoj puni značaj posebno u kontekstu povezivanja s autocestom Zagreb - Split i budućom cestom Žuta Lokva - Križišće.

\subsection{Ribarstvo i marikultura}

Iako su u prošlosti sva velebitska naselja u najvećoj mjeri živjela od stočarstva i poljoprivrede, ribarstvo je također bilo važan izvor priređivanja. U prilog tome govori činjenica da i danas u Vranjaku postoji zgrada ribarske zadruge, a pored nje betonski bazen u kojem su "strojili" ribarske mreže namakajući ih u otopini lista crnike.

Jablanac je krajem 19. stoljeća bio na drugom mjestu u ribarstvu cijelog Hrvatskog primorja (imao je 50 ribara s više brodica i mreža), a u Zavratnici već početkom 20. stoljeća počinje uzgoj školjkaša.

Međutim, sve veći intenzivan ribolov i lov nedopuštenim ribolovnim sredstvima, uzrokovao je osiromašenje biološke osnove priobalnog ribarstva i njegove veće kontrole. Unatoč tome, ipak postoje uvjeti za razvoj ribarstva, naročito marikulture i uzgoj ribe u zaštićenim prirodnim uvalama, pa treba nastojati da se ove privredne djelatnosti potiču.

\subsection{Poljoprivreda i stočarstvo}

Život velebitskih žitelja uglavnom se temeljio na korištenju malih ratarskih površina i na iskorištavanju golemih pašnjačkih prostranstava.

Ratarske primorske padine su zanemarive, rascjepkane na sitne parcele, a zastupljenost raznih kultura (vinova loza, maslina, krumpir, povrće i voće) nije pružalo veće mogućnosti za tržišne viškove. Uzrok tome su skučeni prirodni uvjeti, nepovoljna konfiguracija terena, sastav tla, nedostatak vode i klimatske prilike.

Zarazliku od poljoprivrede, stočarstvoje bilojedna od najvažnijih gospodarskih grana koja postupno odumire razvojem turizma i raseljavanjem stanovništva.

\section{4. Šumarstvo i lovstvo}

Šumarstvo je u prošlosti bila jedna od bitnih gospodarskih grana Velebitskog podgorja. To je posebno dolazilo do izražaja izvozom drva iz visinskih predjela Velebita, jer su šume u primorskom dijelu vrlo rijetke. 


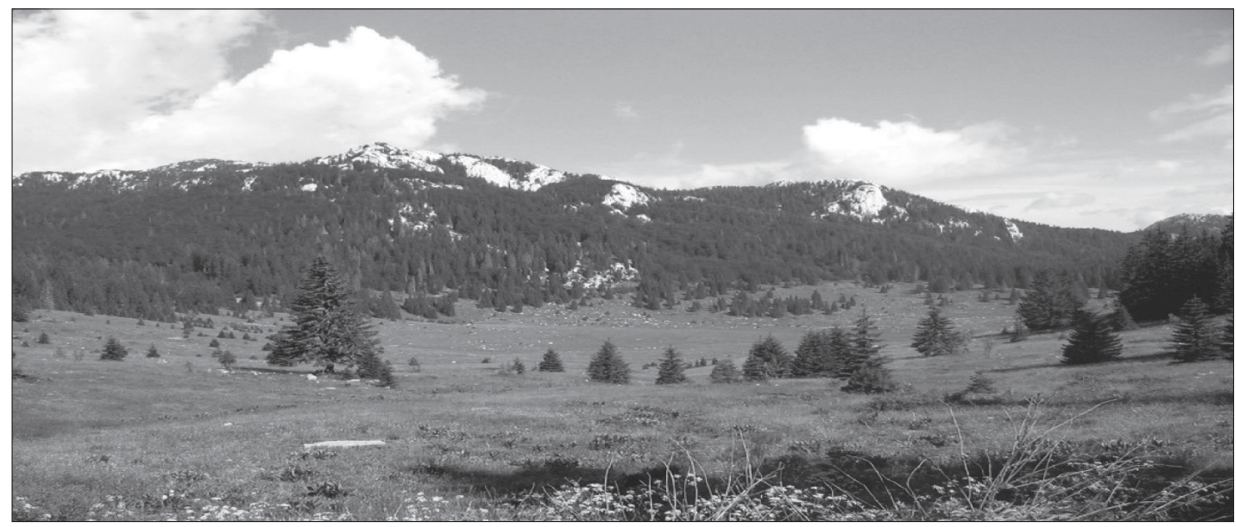

Sl. 2. Velebitski krajolik, izvor: http://www.zastita-prirode.hr/Zasticena-priroda/ Zasticena-podrucja/Nacionalni-parkovi/Nacionalni-park-Sjeverni-Velebit

Za razvoj šumarstva se vezuje i postojanje jedinog industrijskog objekta pilane u Stinici i žičare koja je bila namijenjena prijevozu drva iz gorskih predjela Velebita. Prestankom rada pilane (krajem šezdesetih godina prošlog stoljeća) obustavlja se i promet žičarom, što je utjecalo i na daljnje raseljavanje stanovništva.

Ukupna površina šuma u području parka prirode Velebit obuhvaća 146.532 ha ili $73 \%$ od ukupnih 200.000 hektara površine. ${ }^{4}$ Šume se na ovom području protežu od mora do $1700 \mathrm{~m}$ nadmorske visine, tj. od mediteranske i submediteranske, do subalpske klime na vrhovima Kapele i Velebita. Ekonomske šume pod upravom Senja ili šume šumskog privrednog područja zauzimaju 25.451 ha, od toga 18,32 ha gospodarskih i 7.219 ha zaštićenih šuma (Rožanski kukovi, Štirovača i dr.).

Šume predstavljaju značajnu osnovu razvoja ovog kraja, pri čemu njihova ekološka vrijednost danas višestruko premašuje njihovu sirovinsku vrijednost. Cilj nije samo sačuvati sadašnju površinu šuma, nego uz pošumljavanje povećati površinu. Uz razvoj šumarstva treba posebno poticati i razvoj lovstva te posebno lovnog turizma.

\subsection{Turizam}

Osnovni objektivni razlozi zbog kojih je danas Velebitsko podgorje slabije turistički razvijeno od susjednih regija Kvarnera i Sjeverne Dalmacije su strme obale (problemi pristupa moru i uređenje plaža), nešto oštrija klima (veće prisustvo bure i hladnijih vjetrova) te nedostatak zelenih površina.

${ }^{4}$ Prostorni plan uređenja Grada Senja, 2012, 15. 


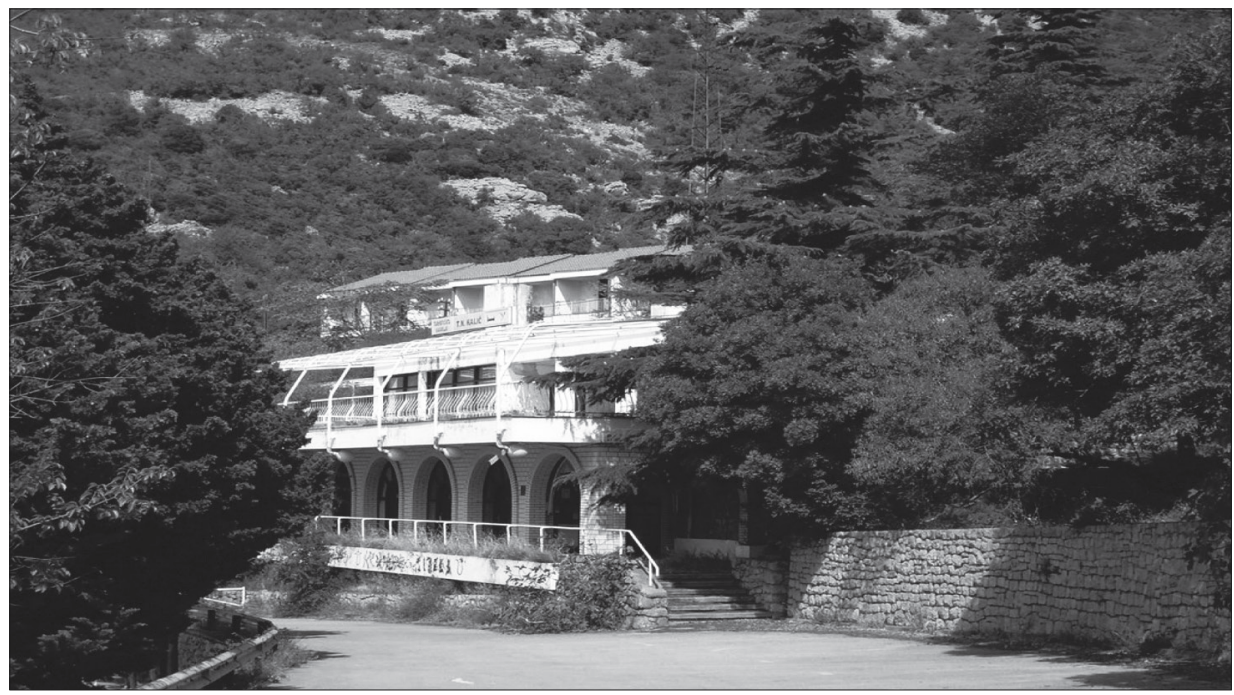

Sl. 3. Motel Kalić, izvor: http://www.panoramio.com/photo/26848978

Priobalno područje turistički je znatno razvijenije od kontinentalnog dijela. Glavnina smještajnih objekata nalazi se uz glavne prometnice, a ne uz turistički najatraktivnije destinacije. Smještajni turistički kapaciteti nisu se u posljednje vrijeme povećavali, a njihova opremljenost je vrlo oskudna. Neki turistički objekti su zapušteni ili van upotrebe (Motel "Kalić", Hotel "Istra" u Sv. Jurju, Motel "Vratnik" i dr.).

Za razliku od primorja, turistički slabije razvijeno planinsko područje svoju privlačnost temelji uglavnom na prirodnim ljepotama planinskog masiva Velebita. Za turističku ponudu izuzetno su važni planinarski domovi i skloništa.

S obzirom na veoma mali broj smještajnih kapaciteta u Parku prirode "Velebit", veliki značaj u budućnosti će imati povećanje smještajnih kapaciteta te razvoj specifičnih vrsta turizma uključujući i razvoj sportsko - rekreacijskog i zimskog turizma. Razvoj turizma trebao bi u budućnosti povoljno djelovati na razvoj poljoprivrede, trgovine, prometa i drugih uslužnih djelatnosti.

\subsection{Industrija, mala privreda, zanatstvo i energetika}

U pravom smislu riječi industrija na području Velebitskog podgorja u prošlosti je bila zanemariva, a i ono malo industrije (drvna industrija, tekstilna i sl.) prestale su s radom. 


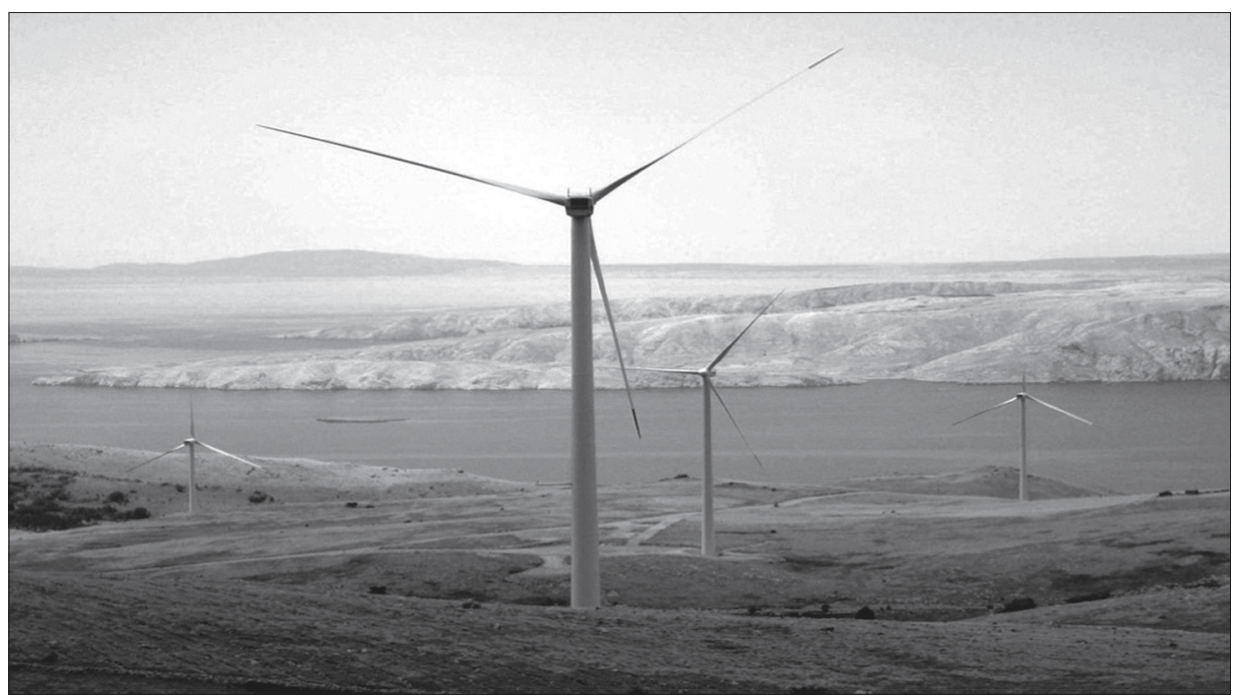

S1. 4. Vjetroelektrana Vrataruša kod Senja, izvor: https://hr.wikipedia.org/wiki/ Vjetroelektrana_Vrataru\%C5\%A1a\#/media/File:Vjetropark_kod_Senja2.JPG

Mala privreda i zanatstvo u prošlosti su imali određeni značaj, ali u postojećim uvjetima su vrlo slabo razvijeni te bi u budućnosti mogli biti jedna od okosnice razvoja.

Za proizvodnju elektroenergije poseban značaj ima izgradnja HE "Senj" (1965.) na području Grabove koja koristi energetske potencijale rijeke Like i Gacke. Određeni pomaci postignuti su i korištenjem vjetroelektrana na području grada Senja, iako upravo u tom segmentu postoje najveći potencijali za dobivanje energije iz prirodnih izvora.

\section{PERSPEKTIVE RAZVITKA VELEBITSKOG PODGORJA}

Prostornim planom uređenja Grada Senja $a^{5}$ utvrđene su osnovne postavke razvitka Velebitskog podgorja do 2020. godine. Prvi i osnovni cilj ovog Plana je zaustavljanje negativnih procesa raseljavanja i daljnje depopulacije ovog kraja. Bez obzira na nepovoljne statističke pokazatelje ovim se planom predviđa blago povećanje broja stanovnika, znatno povećanje životnog standarda, zaštita okoliša te racionalno gospodarenje i korištenje prostora.

${ }^{5}$ Prostorni plan uređenja Grada Senja, 2012, 63. 
U gospodarskoj djelatnosti trebalo bi poticati razvoj malih i srednjih tvrtki i zanatstva. Cilj je razvijanje djelatnosti koje bi angažirale postojeće neiskorištene i napuštene prostore i zemljišta. Osim izgradnje državne cestovne mreže, koja će ovom prostoru omogućiti nove razvojne potencijale, treba graditi i nadopunjavati lokalnu prometnu i drugu infrastrukturnu mrežu radi integriranja udaljenih i slabo nastanjenih područja, te riješiti probleme opskrbe vodom, električnom energijom i javnom odvodnjom što može unaprijediti kvalitetu života u dosada izoliranim područjima.

Potrebno je i valorizirati i izgraditi prometne pravce u funkciji izletničkog turizma i obrane od požara. Razvojni koncept u poljodjelskoj proizvodnji trebao bi se graditi na razvitku malih i srednjih tvrtki s ekološki prihvatljivim proizvodima.

Posebne poticaje treba usmjeriti na drvoprerađivačku proizvodnju, proizvodnju hrane (ekološku proizvodnju), unapređenje stočarstva te turizma orijentiranog na prirodne vrijednosti kojima prostor obiluje - svojevrsnu simbiozu turizma na moru te seoskog, izletničkog, zdravstvenog i ekološkog turizma.

U djelatnosti šumarstva potrebno je i dalje unapređivati gospodarenje šumama te integrirati lovstvo u funkciji razvoja lovnog turizma.

Pojedinačna manja primorska lokalna središta kao što su Sveti Juraj, Jablanac, Stinica, Lukovo, Klada, Starigrad i Prizna posjeduju određeni urbani identitet te ih je potrebno posebno valorizirati u kontekstu razvoja obalnog i nautičkog turizma, te razvitka pomorskog prometa i marikulture.

Na cijelom području Velebitskog podgorja do danas nije izgrađena ni jedna luka nautičkog turizma. U prostornom planu uređenja Grada Senja predviđene su određene luke nautičkog turizma na lokacijama Sv. Juraj (Jablanova), Lukovo, Stinica (Krivača) i Starigrad s ukupno 350 vezova u moru. Osim ovih luka plan određuje lokacije za sportske luke (Sv. Juraj) i ribarske luke (Sv. Juraj i Jablanac) koje čine organizacijske cjeline lučkog prostora.

Planom su određene i potencijalne lokacije za pristaništa i sidrišta (postojeće privezište za smještaj do 10 plovila izvan luke javne namjene nalazi se u uvali Žrnovnica).

Prostornim planom predviđene su i određene lokacije za razvoj marikulture i uzgoj kvalitetne ribe u priobalnom području između Jablanca i Prizne. S obzirom na koncepcije razvoja marikulture koje u posljednje vrijeme preferiraju kavezni uzgoj u akvatoriju većih dubina, obalne lokacije predviđene dosadašnjim planovima nisu za to podobne, pa će stoga biti potrebno utvrditi nove lokacije, jer marikultura treba biti jedna od bitnih razvojnih djelatnosti ovog područja. 


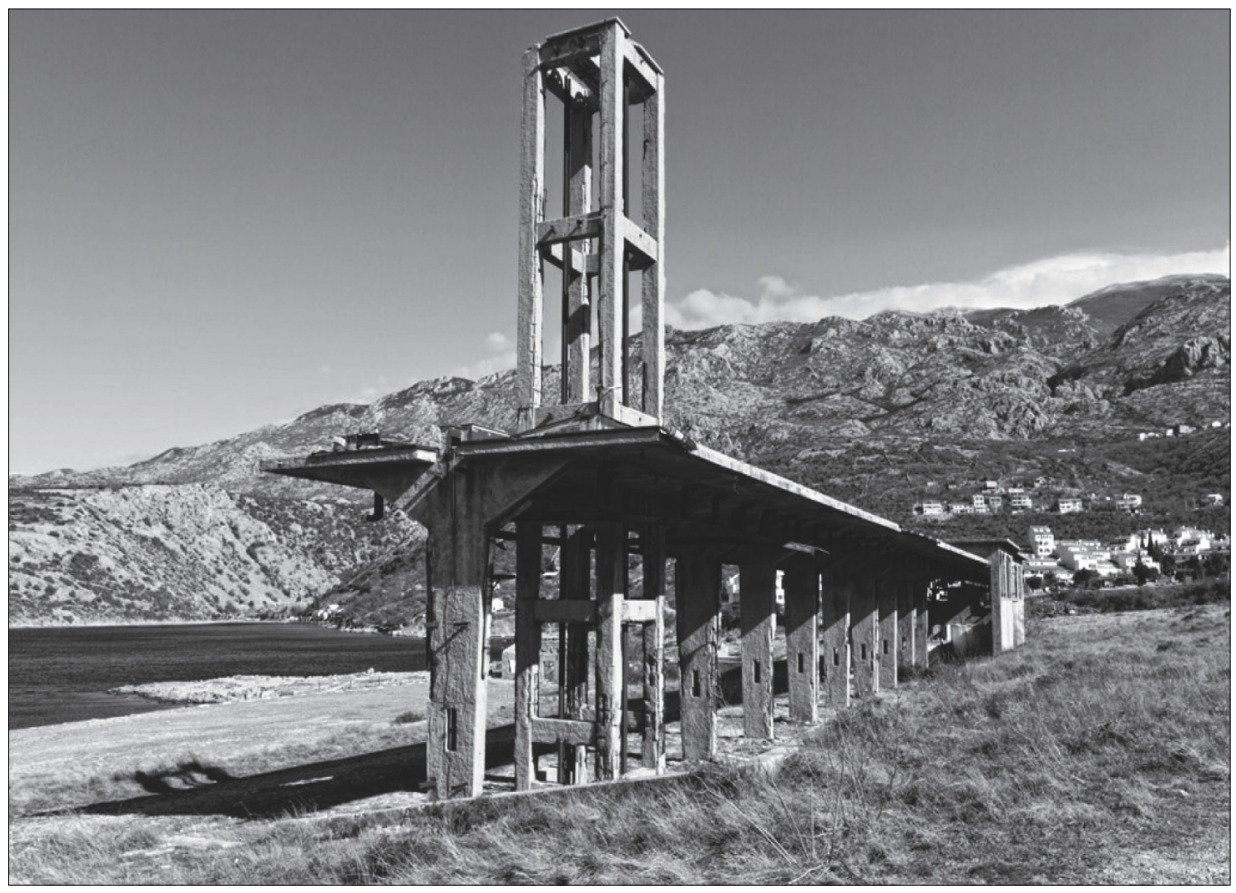

Sl. 5. Ostaci industrijske žičare Stinica - Alan, izvor: http://picugi.blogspot.hr/ 2011/02/zapis-o-velebitskoj-zicari.html

U području pomorskog prometa osim poprečnih veza planom je predviđena uspostava stalne veze među naseljima kvarnerskog i podvelebitskog obalnog pojasa (Rijeka - Crikvenica - Senj - Karlobag - Starigrad) te brze i frekventne čarter veze na lokalnoj razini između Senja i priobalnih naselja Podgorja tijekom cijele godine.

Za razvitak turizma posebno bi bilo važno povezivanje obalnog pojasa s brdskim predjelima Velebita što bi se omogućilo revitalizacijom žičare.

$\mathrm{U}$ iskorištavanju energetskih potencijala, posebice alternativnih i obnovljivih izvora energije, područje Velebitskog podgorja ima poseban značaj. Zbog toga je potrebno uzeti u obzir snagu vjetra i nastaviti ispitivanja koja su započeta na Vratniku. Ovakvi projekti imaju bitan značaj, posebno ako se dokaže njihov neznatan utjecaj u pogledu buke i narušavanja estetskih i ekoloških kriterija. 


\section{SWOT ANALIZA POTENCIJALNIH MOGUĆNOSTI I REVITALIZACIJE VELEBITSKOG PODGORJA}

S (Strengths), W (Weaknesses), O (Opportunities) i T (Threats) analiza je integralni analitički okvir za analizu vanjskih i unutarnjih parametara razvitka određenog područja. Definirajući prednosti, nedostatke, snage i slabosti određenog područja moguće je utvrditi strategiju i pravce razvoja.

Snage su ona pozitivna unutarnja svojstva koja mogu određenom području osigurati konkurentsku prednost.

Slabosti su svojstva koja smanjuju konkurentnu sposobnost, kao što je nedostatak vizije, znanja, neadekvatna alokacija i upotreba raspoloživih resursa i dr.

Prilike su trenutni ili budući uvjeti i promjene u okolini koje se mogu iskoristiti za poboljšanje konkurentnosti i uspješnosti. To su u biti šanse koje treba prepoznati, npr. u promjenama zakonskih uvjeta, poreznoj politici, specifičnim potrebama korisnika, novim tehnologijama, nedostatcima konkurencije i svemu onome što omogućava postizanje utvrđenog strateškog cilja.

Prijetnje su ona postojeća ili buduća svojstva i uvjeti okoline koji imaju, ili će u budućnosti imati, negativan utjecaj na uspješnost razvoja određenog područja.

Shodno navedenom, SWOT analiza omogućava i zahtjeva sustavnu analizu funkcioniranja svih procesa i postojeće tehnologije u zavisnosti od dostignutog stupnja organizacijskog razvoja i raspoloživih resursa. U navedenoj tablici navedena je SWOT matrica za utvrđivanje strategije razvoja Velebitskog podgorja.

U razmatranjima istaknutih značajki SWOT analize ovog područja naglasak je bio da je prednosti - potrebno istaknuti, nedostatke - smanjiti, mogućnosti - iskoristiti, a prijetnje - izbjeći.

Odabir razvojnog modela ovog područja stoga bi se trebao temeljiti na sljedećim preduvjetima:

- racionalno korištenje prirodne resursne osnove i bioloških raznolikosti

- prometno povezivanje (izgradnja odgovarajućih cestovnih prometnica) i izgradnja komunalne infrastrukture

- uvažavanje mjera zaštite okoliša i stvaranje preduvjeta za razvoj turizma, poljodjeljstva, stočarstva, seoskog turizma

- očuvanje kulturnih i povijesnih osobitosti

- poticanje razvoja male privrede i zanatstva

- poticanje razvoja šumarstva i prerađivačke industrije

- poticanje razvoja marikulture

- poticanje razvoja luka nautičkog turizma

- poticanje razvoja specifičnog oblika turizma (obalnog, zdravstvenog, lovnog, sportsko - rekreacijskog, zimskog i dr.) 
- poticanje povezivanja obalnog i gorskog područja

- demografska obnova ovog područja

- primjerena porezna politika države koja će poticati razvoj nedovoljno naseljenih obalnih i planinskih područja

- privlačenje sredstava EU radi razvoja komunalne infrastrukture.

Tablica 1. SWOT matrica potencijalnih prednosti i ograničenja razvitka Velebitskog podgorja

\begin{tabular}{|c|c|}
\hline Prednosti (unutarnje obilježje) & Nedostatci (unutarnje obilježje) \\
\hline 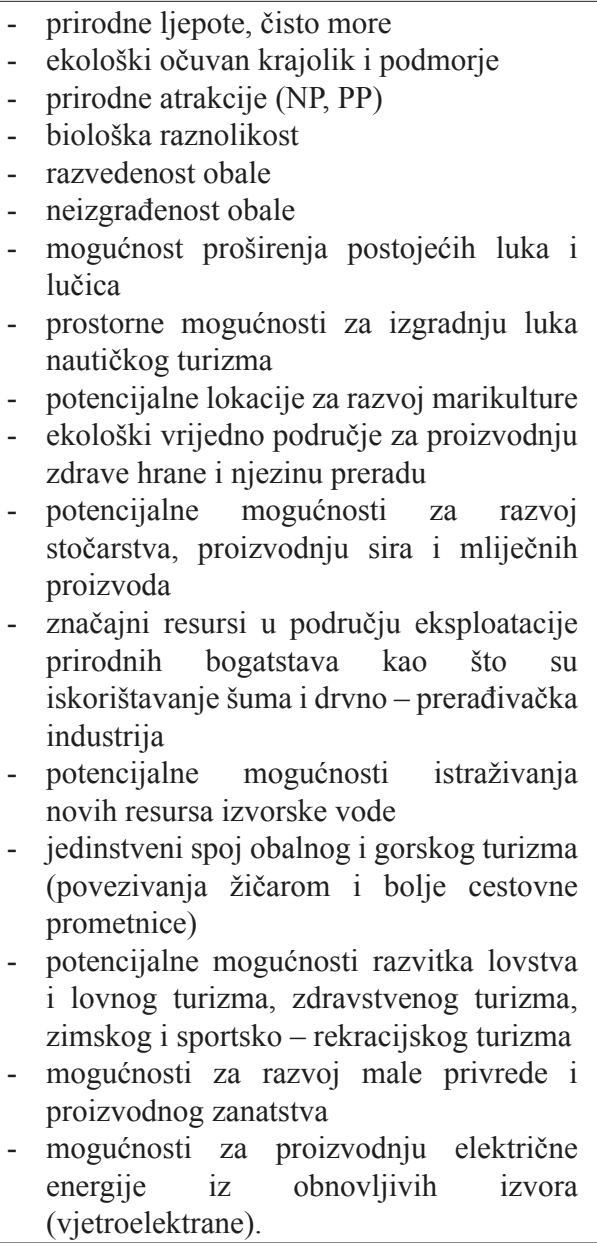 & $\begin{array}{l}\text { - } \text { raseljenost stanovništva (veliki broj } \\
\text { napuštenih sela i naselja) } \\
\text { - nedostatak prometnih veza između } \\
\text { pojedinih naselja uz obalu } \\
\text { - izuzetno loše prometne veze (cestovne } \\
\text { prometnice) između obalnih i planinskih } \\
\text { predjela } \\
\text { nedostatak odgovarajuće komunalne } \\
\text { infrastrukture u većem broju naselja } \\
\text { (energetska, vodovodna i kanalizacijska } \\
\text { mreža) } \\
\text { - nedostatak bilo kakve industrije i } \\
\text { malopreprađivačke proizvodnje } \\
\text { - nedostatak pomorskih prometnih veza i } \\
\text { luka nautičkog turizma } \\
\text { nemogućnost izgradnje objekata unutar } \\
\text { nacionalnog parka i parka prirode Velebit } \\
\text { te posebnih rezervata botaničkih vrtova i } \\
\text { spomenika prirode } \\
\text { - nedovoljan broj međunarodnih projekata } \\
\text { - ograničenost područja za razvoj ribolova i } \\
\text { marikulture } \\
\text { - skromni smještajni kapaciteti s lošom } \\
\text { infrastrukturom za razvoj turizma } \\
\text { - nedostatak planinarskih domova i skloništa } \\
\text { za razvoj zimskog i lovnog turizma } \\
\text { - problemi pristupa moru i uređenje plaža } \\
\text { - neodgovarajuće zbrinjavanje otpada } \\
\text { - nedostatak odgovarajuće strategije } \\
\text { razvoja. }\end{array}$ \\
\hline
\end{tabular}




\begin{tabular}{|c|c|}
\hline $\begin{array}{c}\text { Mogućnosti (kao posljedica vanjskih } \\
\text { utjecaja) }\end{array}$ & Prijetnje (kao posljedica vanjskih utjecaja) \\
\hline $\begin{array}{l}\text { - ulazak u EU i otvaranje jedinstvenog } \\
\text { tržišta } \\
\text { - očuvanost prirodne okoline u relativno } \\
\text { velikom prostoru s atraktivnim pejzažima } \\
\text { i mnogobrojnim prirodnim rijetkostima } \\
\text { (zbog kojih je Velebit uvršten u Registar } \\
\text { UNESCO-a kao Svjetski rezervat biosfere) } \\
\text { - porast mobilnosti turista i veći interes za } \\
\text { nova turistička područja koja stavljaju u } \\
\text { prvi plan ekološke, prirodne, zdravstvene } \\
\text { i atrakcijske kvalitete } \\
\text { - mogućnost povezivanja obalnog i } \\
\text { planinskog područja te ponuda autohtonih } \\
\text { poljoprivrednih i stočarskih proizvoda } \\
\text { - mogućnost razvitka luka nautičkog } \\
\text { turizma manjih kapaciteta } \\
\text { - mogućnost razvoja marikulture i ribarstva } \\
\text { - razvoj pomorsko - putničkog prometa i } \\
\text { integracija s cestovnim prometnicama } \\
\text { - unapređenje prometne dostupnosti } \\
\text { (izgradnja odgovarajućih prometnih veza } \\
\text { između naselja) } \\
\text { - } \text { razvoj ekoturizma, lovnog turizma i male } \\
\text { privrede } \\
\text { - privlačenje stranih ulaganja u energetski } \\
\text { obnovljive izvore energije (potencijali } \\
\text { vjetra i sunca) } \\
\text { - povlačenje stranih ulaganja za izgradnju } \\
\text { odgovarajuće komunalne infrastrukture. }\end{array}$ & 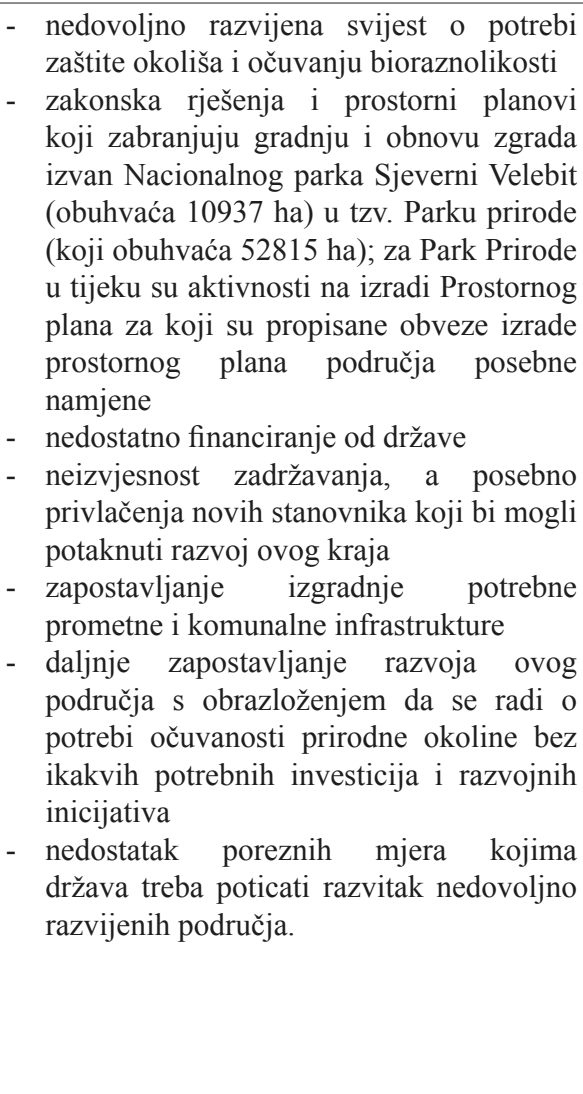 \\
\hline
\end{tabular}

Izvor: izradili autori

\section{ZAKLJUČAK}

Gospodarske i društvene aktivnosti planirane na području Velebitskog podgorja predstavljaju okosnicu društvenog i ekonomskog razvoja i poticaj reverzibilnim procesima demografskog oporavka. Iako gospodarske aktivnosti treba poticati u onim područjima gdje postoji radno aktivno stanovništvo, treba stvoriti i uvjete za povratak raseljenih, ali i dolazak novih stanovnika koji će se aktivno uključiti u revitalizaciju ovog kraja. Gospodarske aktivnosti u ovom području treba ponajprije razvijati oslanjajući se na tradiciju, a da bi to bilo moguće uglavnom je potrebna izgradnja odgovarajuće prometne i komunalne infrastrukture, te energetske mreže tamo gdje ona nedostaje. Zbog toga se $u$ 
prvom planu ističe eksploatacija prirodnih bogatstava kao što je iskorištavanje šuma i drvno - prerađivačka industrija, razvoj poljoprivrede i stočarstva, razvoj malog poduzetništva, razvoj turizma, marikulture i eksploatacije prirodnih energetskih potencijala.

U budućnosti očekuje se i značajan razvoj turizma kao visokoproduktivne djelatnosti, u kojoj dolazi do mijenjanja potrošačkih navika, želja i očekivanja koja više nisu orjentirana samo prema sezonskom turizmu uz more, nego i prema kombinacijama i najrazličitijim prostornim atrakcijama.

U tom kontekstu i zdravstveni, planinarski i lovni turizam mogu biti jedan od pokretača razvoja.

Potencijalni nositelji gospodarskog rasta mogu biti i tvrtke i obrtnici koji će naći svoj interes u razvoju turističke ponude.

U pomorskom prometu razvoj je potrebno temeljiti na razvoju boljih pomorskih veza između naselja, dostupnosti obalnih područja, uređenju plaža te izgradnji manjeg broja luka nautičkog turizma.

U povezivanju obalnih i planinskih predjela važnu ulogu imala bi i obnova prijašnje žičare. To bi znatno unaprijedilo atraktivnost ovog područja jer bi turisti mogli svoj odmor provoditi na moru, ali i u planinskim predjelima za vrijeme ljetnih vrućina.

Značajni uvjeti postoje i za razvoj marikulture koja može biti na principu monokulturnog ili polikulturnog tipa (paralelni uzgoj riba i školjkaša). Razvedenost morske obale i čistoća mora, pogodnosti su za razvoj sportskog ribolova koji bi mogao postati važan čimbenik u rekreaciji stanovnika i turista.

S obzirom na prirodne potencijale i klimu ovog područja (učestalost i snagu vjetra) bitna pretpostavka razvitka ovog kraja i iskorištavanje obnovljivih izvora energije (vjetra i sunca).

Planskim mjerama potrebno je potaknuti razvoj gospodarskih (proizvodnih, trgovačkih, slobodnih i carinskih zona) što će omogućiti brži razvitak ovog kraja.

Naglasak bi ponajprije trebao biti na razvitku malih i srednjih tvrtki s ekološki prihvatljivim proizvodima, privlačenju većih sredstava iz EU fondova i ulaganja stranih investitora.

\section{Literatura}

Ana LEMIĆ, Sela i stanovi na Velebitu - Svjedočanstva od nastanka do nestanka, Zagreb, 2013.

Prostorni plan uređenja Grada Senja, 1. Polazišta, Sveučilište u Zagrebu, Arhitektonski fakultet, Zagreb, 2012. 
Pavle ROGIĆ, Naseljenost Velebitske primorske padine kroz historiju, Senjski zbornik, I, Senj, 1965, 35-68.

Veljko ROGIĆ, Položaj Senja i gravitacija, Senjski zbornik, I, Senj, 1965, 7-21.

\section{THE POTENTIALS AND PERSPECTIVES OF THE DEVELOPMENT OF VELEBIT PODGORJE}

\section{Summary}

Velebit is not only the largest Croatian mountain but is the only littoral mountain that divides two geographically essentially diverse areas: the Mediterranean and continental mountain regions, in other words, the Croatian Littoral from Mountain Croatia. The littoral slope of Velebit includes Podgorje which begins near Sveti Juraj where it gradually spreads and rises to Jablanac, whilst in the southern part Velebit gradually passes into the northern - Dalmatian karst plateau. The natural conditions and setting along the sea have contributed in the past to the development of forestry, agricultural and livestock production, shipping, fishing, trade, hunting and tourism. The transport connectivity of the settlements of the Velebit littoral slope with the outside world always took place via the sea, because there were no land routes or they were in such a state that they did not allow a better connection between the settled places. The population coverage of their region is dominated by numerous hamlets, $1-6 \mathrm{~km}$ apart and set in the interior from the sea mostly in the central vegetational belt because bare rock dominates along the coastline. Nature has influenced this separation because any settlements had to be placed where the 'bura' does not blow. Due to this in the Velebet littoral area, with the exception of Senj, three more important coastal settlements developed: Sveti Juraj, Jablanac and Karlobag. The lack of traffic and communal infrastructure and other necessary amenities (educational, health, economic and so on) are the reason for the large depopulation of this area which in modern conditions is one of the least populated regions of the Republic of Croatia. However, the potential values of this region point to the possibilities of its speedier development. The aims and guidelines of development point primarily to the protection of the natural and cultural resources with an emphasised need in making developmental economic programmes. Besides the development of a road network which in this area would prompt new developmental potentials with the planned measures of development, the development of economic activities (development of tourism, mariculture, nautical tourism ports, health-recreational tourism, hunting tourism, fruit growing and horticulture, livestock breeding, forestry and timber - manufacturing activities, the use of the energy potentials of the wind and sun, the development of manufacturing, trade and free customs zones and so on) and social activities in the decentralisation of the system of centralised settlements (educational, health and cultural infrastructure) should be stimulated. In this paper a special emphasis is made on the appraisal of the natural potentials, of sustainable development and the evaluation of the possibility of the revitalisation of Podgorje. To this end a SWOT analysis was produced as a basic prerequisite for future development.

Keywords: Velebit Podgorje, potentials, perspectives of development, sustainable development, SWOT analysis, economic and social development 